University of Nebraska - Lincoln

DigitalCommons@University of Nebraska - Lincoln

Using Plasma-Lipid Metabolites to Index Changes in Lipid Reserves of Free-Living Lesser Scaup (Aythya affinis)

Michael Anteau

Louisiana State University, Baton Rouge,, manteau@usgs.gov

Alan Afton

U.S. Geological Survey

Follow this and additional works at: https://digitalcommons.unl.edu/usgsnpwrc

Part of the Other International and Area Studies Commons

Anteau, Michael and Afton, Alan, "Using Plasma-Lipid Metabolites to Index Changes in Lipid Reserves of Free-Living Lesser Scaup (Aythya affinis)" (2008). USGS Northern Prairie Wildlife Research Center. 13. https://digitalcommons.unl.edu/usgsnpwrc/13

This Article is brought to you for free and open access by the US Geological Survey at DigitalCommons@University of Nebraska - Lincoln. It has been accepted for inclusion in USGS Northern Prairie Wildlife Research Center by an authorized administrator of DigitalCommons@University of Nebraska - Lincoln. 


\title{
USING PLASMA-LIPID METABOLITES TO INDEX CHANGES IN LIPID RESERVES OF FREE-LIVING LESSER SCAUP (AYTHYA AFFINIS)
}

\author{
Michael J. Anteau ${ }^{1,3}$ and Alan D. Afton ${ }^{2}$ \\ ${ }^{1}$ School of Renewable Natural Resources, Louisiana State University, Baton Rouge, Louisiana 70803, USA; and ${ }^{2}$ U.S. Geological Survey, \\ Louisiana Cooperative Fish and Wildlife Research Unit, Louisiana State University, Baton Rouge, Louisiana 70803, USA
}

\begin{abstract}
AвSTRACT.-Understanding daily lipid-reserve changes in migrating wild birds is important for habitat assessment and species conservation. Plasma-lipid metabolites have been used to estimate rates of lipid accumulation or catabolism in small-bodied wild birds $(<75 \mathrm{~g})$, but this has not been validated for larger-bodied wild birds such as waterfowl. We developed an index for detecting whether individual birds accumulate or catabolize lipid reserves by regressing plasma-lipid metabolite levels (triglyceride and $\beta$-hydroxybutyrate) and known one-day mass changes (daily mass change) of 22 free-living Lesser Scaup (Aythya affinis; a larger-bodied species with typical mass range 600-1,000 g). Triglyceride and $\beta$-hydroxybutyrate predicted $75 \%$ of the variation in daily mass change $(F=28.85$, $\mathrm{df}=2$ and $19, P<0.001)$. Triglyceride was positively correlated $(P=0.029)$ with mass change, and $\beta$-hydroxybutyrate was negatively correlated $(P<0.001)$ with mass change (daily mass change $=-54.49+11.82$ [triglyceride] $-28.65\left[\beta\right.$-hydroxybutyrate $\left.\left.{ }_{\text {log }}\right]\right)$. Our results indicate that triglyceride and $\beta$-hydroxybutyrate can estimate one-day changes in mass of free-living wild Lesser Scaup, which provides an index to daily changes in lipid reserves and should be useful for assessing quality of migration habitat. Received 2 December 2006 , accepted 14 July 2007.
\end{abstract}

Key words: Aythya affinis, catabolism, fattening, Lesser Scaup, mass change, metabolites, migration.

\section{Uso de Metabolitos Lipídicos del Plasma como un Índice de Cambios en la Reservas de Individuos de la Especie Aythya affinis de Vida Libre}

RESUMEN.-Entender los cambios diarios en las reservas lipídicas en aves migrantes silvestres es importante para evaluar los hábitats y para la conservación de las especies. Los metabolitos lipídicos presentes en el plasma han sido utilizados para estimar las tasas de acumulación de lípidos o catabolismo en aves silvestres de tamaño pequeño $(<75 \mathrm{~g})$, pero no existe una validación de esta relación para aves silvestres de tamaño más grande como las anseriformes. Desarrollamos un índice para detectar si los individuos acumulan o catabolizan reservas lipídicas mediante un análisis de regresión entre los niveles de metabolitos lipídicos en el plasma (triglicéridos y $\beta$-hidroxibutirato) y cambios conocidos en la masa corporal sucedidos en un día (cambio diario en el peso) de 22 individuos de vida libre de Aythya affinis, una especie de tamaño corporal más grande cuya masa corporal típica está en un rango de 600 a 1000 g. Los triglicéridos y el $\beta$-hidroxibutirato predijeron el $75 \%$ de la variación en el cambio diario en la masa corporal $(F=28.85$, g.l. $=2$ y $19, P<$ 0.001). Los triglicéridos se correlacionaron positivamente $(P=0.029)$ y el $\beta$-hidroxibutirato $(P<0.001)$ negativamente con el cambio en la masa corporal (cambio diario en la masa $=-54.49+11.82$ [triglicéridos] -28.65 [ $\beta$-hidroxibutirato ${ }_{\text {log }}$ ). Nuestros resultados indican que los triglicéridos y el $\beta$-hidroxibutirato pueden estimar los cambios en la masa corporal sucedidos en un día en individuos silvestres en A. affinis, lo que provee un índice de los cambios diarios en las reservas de lípidos, y puede ser útil para evaluar la calidad de los ambientes de migración.

NUTRIENT RESERVES ACQUIRED during migration are important determinants of survival and influence reproductive success in some birds (Afton and Ankney 1991, Alisauskas and Ankney 1992, Pace and Afton 1999, Lindström 2003, Anteau and Afton 2004). Information on whether an individual is catabolizing or accumulating lipid reserves would be helpful in making inferences about habitat quality on specific migration-stopover areas. However, traditional measures of body condition (e.g., size-adjusted body mass and lipid, protein, and mineral reserves) are influenced by a combination of environmental factors at collection sites and

${ }^{3}$ Present address: U.S. Geological Survey, Northern Prairie Wildlife Research Center, Jamestown, North Dakota 58401, USA. E-mail: manteau@usgs.gov

The Auk, Vol. 125, Number 2, pages 354-357. ISSN 0004-8038, electronic ISSN 1938-4254. 
previous stopover areas (Anteau and Afton 2004). For example, birds collected from two stopover sites could have similar body mass and lipid reserves, but birds at one site might be accumulating lipid reserves, whereas those at the other might be catabolizing lipid reserves, resulting in opposite implications for habitat quality (Williams et al. 1999).

Plasma-lipid metabolites (triglycerides [TRIG], glycerol [GLY], and $\beta$-hydroxybutyrate [BOHB]) may be useful tools for estimating lipid accumulation or catabolism in free-living wild birds (Jenni-Eiermann and Jenni 1994, Williams et al. 1999). Triglycerides are the predominant form of energy-storage in birds and are composed of fatty acids and GLY (Ramenofsky 1990). Fatty acids are used for energy through $\beta$-oxidation (catabolism of lipids), and GLY is used for storage and transport of fatty acids (Ramenofsky 1990). Therefore, TRIG concentration is positively correlated with lipid deposition into adipose tissue, whereas GLY is released into plasma when fatty acids are oxidized but also may be released during deposition (through mobilization of GLY to deposition sites), potentially resulting in a U-shaped curve in relation to lipid change (Ramenofsky 1990, Guglielmo et al. 2005). $\beta$-hydroxybutyrate is a ketone body and a byproduct of $\beta$-oxidation; thus, it is positively correlated with rates of lipid catabolism (Ramenofsky 1990).

Analyses of the relationships between lipid-reserve changes and TRIG, GLY, and BOHB have generally been conducted by (1) examining metabolite levels of captive birds in relation to days fasted (e.g., Le Maho et al. 1981, Boismenu et al. 1992) or changes in body mass (as an index for changes in lipid reserves) (e.g., JenniEiermann and Jenni 1994, Williams et al. 1999); (2) examining differences in metabolites of wild birds between habitats of differing quality (e.g., Guglielmo et al. 2002, 2005); or (3) examining differences in metabolites of wild birds in relation to daily feeding patterns (e.g., Jenni and Jenni-Eiermann 1996). An evaluation of how plasma-lipid metabolites estimate changes in lipid reserves of wild migratory birds would be useful because captive and freeliving birds have differing activity levels. Moreover, most of the previous work on these relationships has been conducted on small-bodied bird species (i.e., <75 g). Accordingly, we developed an index for detecting changes in lipid reserves in free-living wild Lesser Scaup (Aythya affinis; hereafter "scaup"), a larger-bodied bird (600-1,000 g), by regressing plasma-lipid metabolite levels (TRIG, GLY, and BOHB) to known one-day mass changes (daily mass change $[\mathrm{DMC}])$.

\section{Methods}

Study area.-In springs 2004 and 2005 (13-30 March), we captured and banded wild scaup at Pool 19 of the Mississippi River between Hamilton and Dallas City, Illinois, and Keokuk and Ft. Madison, Iowa. Pool 19 is used extensively by scaup during spring migration and has been described in detail by Thompson (1973).

Capture, recapture, and bleeding.-We captured scaup using swim-in and dive-in traps (Haramis et al. 1982) baited with corn. We checked traps and removed birds twice a day (approximately 1000 and 1800 hours). Captured scaup were held for $\sim 2 \mathrm{~h}$ (to minimize contribution of ingesta to body-mass measurements), weighed $( \pm 1 \mathrm{~g})$, banded, and released. We excluded birds from this experiment that had food present in their crop, as determined by palpation.

We extracted $1 \mathrm{~mL}$ of blood from the brachial vein (25gauge needle) of recaptured scaup soon after removal from the trap (approximately 5-25 min). We transferred blood slowly into a $1.5-\mathrm{mL}$ heparinized micro-centrifuge tube and placed it in a cooler (not in direct contact with ice). Blood samples were centrifuged at 6,000 rpm $(2,000 \times \mathrm{G})$ for 5-10 min, and plasma was transferred into new vials and frozen within $2-3 \mathrm{~h}$ of collection $\left(-20^{\circ} \mathrm{C}\right.$; Guglielmo et al. 2002). We recaptured, weighed, and collected blood from 111 individuals; 12 individuals were recaptured two or more times.

Plasma-lipid metabolite assays. - Total triglycerides (TRIG + GLY) and GLY were measured by endpoint assay (Williams et al. 1999, Guglielmo et al. 2002, Anteau 2006). We calculated TRIG by subtracting GLY from total triglycerides (Williams et al. 1999, Guglielmo et al. 2002). We measured BOHB by kinetic assay (Guglielmo et al. 2005, Anteau 2006). All plasma-lipid metabolite assays were read on a microplate spectrophotometer (Thermo Lab Systems, Model 1500, Milford, Massachusetts).

Statistical analysis.-We limited our analysis to birds recaptured within one day of previous capture $(n=22$, all males) because plasma-lipid metabolite levels change rapidly (Jenni and Jenni-Eiermann 1996), as do rates of mass change in scaup (data based on multiple captures of individuals; Anteau 2006). We calculated the mass change for each individual (recapture mass mass from previous day).

We used multiple regression to evaluate whether levels of TRIG, GLY, and BOHB predicted mass change of scaup (PROC REG; SAS Institute 2002). We initially included recapture body mass and both linear and quadratic terms for GLY and examined residuals to determine whether transformations of the data were necessary; we subsequently natural-log-transformed (ln) BOHB because the relationship between non-transformed BOHB and DMC was curvilinear. We selected the final model using backwards-elimination procedures ( $\alpha=0.05$; Zar 1996).

\section{Results}

One-day mass changes ranged from -68 to $61 \mathrm{~g}$, and $45 \%$ of the 22 scaup gained mass. Plasma-lipid metabolites had the following ranges $\left(\mathrm{mmol}^{*} \mathrm{~L}^{-1}\right)$ : GLY $(0.263-2.303)$, TRIG $(0.391-3.775)$, and BOHB (0.128-2.064).

Levels of TRIG and BOHB predicted mass change well $\left(R^{2}=\right.$ $0.75 ; F=28.85, \mathrm{df}=2$ and $19, P<0.001)$. TRIG was positively correlated with mass change (estimate $=11.82, t=2.36, \mathrm{df}=1$ and $19, P=0.029)$, whereas BOHB $(\ln )$ was negatively correlated with mass change (estimate $=-28.65, t=-4.29, \mathrm{df}=1$ and $19, P<0.001$ ). Recapture body mass and linear or quadratic terms for GLY were not significant $(P>0.05)$ and were excluded. TRIG and BOHB $(\ln )$ appeared to be linearly related to mass change (Fig. 1 ). Therefore, the final regression equation was as follows.

$$
\mathrm{DMC}=-54.49+11.82(\mathrm{TRIG})-28.65\left(\mathrm{BOHB}_{\mathrm{ln}}\right)
$$




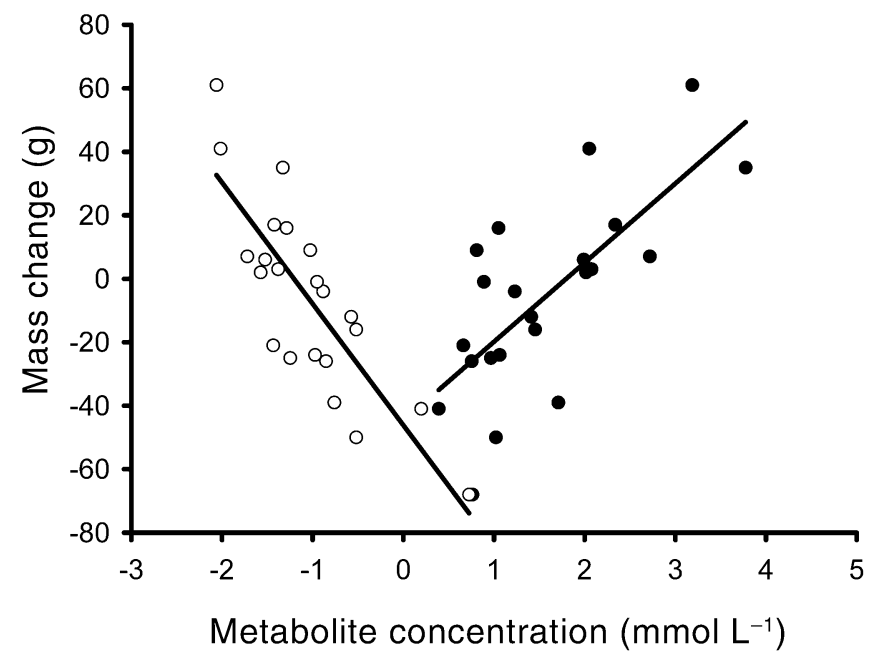

FIG. 1. Relationships of triglycerides (TRIG) and natural-log $\beta$-hydroxybutyrate $(\mathrm{BOHB})$ to one-day mass changes of Lesser Scaup staging at Pool 19 of the Mississippi River during spring migration 2004 and 2005. Filled circles represent TRIG, and unfilled circles represent BOHB.

\section{Discussion}

The relationships we observed among TRIG, BOHB, and DMC in wild Lesser Scaup were generally consistent with those from experiments on captive Western Sandpipers (Calidris mauri), Garden Warblers (Sylvia borin), Cedar Waxwings (Bombycilla cedrorum), and White-crowned Sparrows (Zonotrichia leucophrys) (Jenni-Eiermann and Jenni 1994, Williams et al. 1999, Cerasale and Guglielmo 2006). In Domestic Geese (Anser domesticus) and captive Greater Snow Geese (Chen caerulescens atlantica), BOHB increased as birds were fasted until lipid reserves were completely catabolized during starvation (Le Maho et al. 1981, Boismenu et al. 1992). Thus, studies of captive and free-living birds produce similar relationships between body-mass change and plasma TRIG and BOHB.

We detected no significant relationship between GLY and DMC in free-living scaup. Jenni and Jenni-Eiermann (1996) found that GLY did not vary with time since nightly fast in several species of free-living wild birds, and other studies have shown that GLY was similar in birds captured in habitats of differing quality, except in American Robins (Turdus migratorius; Guglielmo et al. 2002, 2005). However, GLY increased with loss of body mass in captive Western Sandpipers and Garden Warblers (Jenni-Eiermann and Jenni 1994, Williams et al.1999). These inconsistent results among studies suggest that GLY is likely influenced by many factors (e.g., activity levels) that are difficult to control in studies of free-living birds.

Daily changes in body mass could be caused by changes in lipid reserves, ingesta, or protein reserves, though previous work on scaup and the design of our study make it likely that measured changes in body mass were almost entirely lipid. Size-adjusted protein reserves of scaup staging at Pool 19 during the middle of March in 2000 and 2001 varied little among individuals $(158.8 \pm 10.1$ [SD] g; Anteau 2002), which suggests that daily change in body mass is unlikely to involve much protein. We controlled, to some extent, for the effect of ingesta mass on daily change in body mass by holding birds for $\sim 2 \mathrm{~h}$ before weighing and not including birds with palpable crop contents in the analysis. However, ingesta likely contributed to some of the measured daily change in scaup body mass. Regardless, changes in ingesta and protein reserve mass would influence our estimates only if they were correlated with changes in lipid reserves because our model examined lipid metabolites.

Our model of TRIG and BOHB predicted $75 \%$ of the variation in mass change, despite the potential variability associated with ingesta mass. Feeding rates and digestion of food are likely correlated with TRIG and BOHB (see Jenni and Jenni-Eiermann 1996, Zajac et al. 2006); thus, we assume that ingesta mass was positively correlated to changes in lipid reserves. Therefore, our model should be reliable for evaluating whether or not an individual is accumulating or catabolizing lipid reserves and making comparisons of DMC between areas, but it is probably less reliable for estimating the actual rate of change in lipid reserves $\left(\mathrm{g} \mathrm{day}^{-1}\right)$. Amounts of ingesta and feeding rates could be better controlled in a study of captive scaup, through timing of meals and mass measurements or by using alternative indexes of lipid reserves (e.g., total body electrical conductivity; Roby 1991).

We were unable to examine potential sexual differences in the relationship between plasma-lipid metabolites and DMC because males were more numerous and easier to capture. However, there is little reason to assume that males and females would have different relationships between plasma-lipid metabolites and DMC in spring. Boismenu et al. (1992) reported that daily levels of BOHB of fasting Greater Snow Geese were similar between sexes. Additionally, male and female scaup consume similar foods and forage in the same habitats during spring migration (Anteau 2006, Anteau and Afton 2006). However, these relationships will likely differ when females initiate rapid development of ovarian follicles (usually in June), when large amounts of lipids are mobilized to reproductive tissue (Ramenofsky 1990).

Lipid metabolite concentrations change rapidly in plasma of birds; thus, mass changes can be predicted within a period of $2 \mathrm{~h}$ to two days (Jenni and Jenni-Eiermann 1996, Williams et al. 1999). Accordingly, our model should be valuable in assessing whether scaup are accumulating or catabolizing lipid reserves at particular stopover areas during migration on the basis of concentrations of TRIG and BOHB. Additionally, our model should be particularly valuable for identifying areas of high and low habitat quality in relation to the nutritional needs of migrating scaup. Moreover, until now the relationship between metabolite concentrations and mass change had not been validated in the field with free-living birds or larger-bodied birds (>75 g). Therefore, our results, coupled with those of previous studies on passerines and shorebirds, indicate that this technique is a valuable tool for assessing habitat quality.

\section{ACKNOWLEDGMENTS}

We thank those who assisted with banding: C. Adams, L. Ball, L. Bollman, M. Bowyer, J. Boze, R. Brady, M. Chandler, T. Coon, K. Deisanti, R. Domazlicky, G. Dunn, K. Eastman, D. Fronczak, A. Greer, N. Hanke, C. Harsen, L. Hartner, K. Harvey, B. Hill, C. Hine, M. Hodge, D. Johnson, M. Jones, R. Kelly, T. Krumwiede, A. Leach, D. Major, P. Mathews, M. McGinty, B. Meixell, E. Merritt, D. Mitchell, T. Mulcahy, R. Olsen, B. Poulter, A. Raedeke, A. Robbins, M. Sapponton, E. Shank, C. Smith, 
P. Stogdill, A. Tappmeyer, R. Tebbs, J. Tharp, C. Trine, M. Wallendorf, T. Weinman, R. Wesselschmidt, K. Westphall, and A. Yetter. We are grateful for logistical field support provided by R. Anderson, J. Bergman, H. Courtois, D. Graber, A. Hancock, S. Havera, D. Holm, S. Jenkins, T. Leifield, R. Marshalla, B. Ohde, M. Szymanski, and S. Yaich. We are indebted to J. Francis for letting us use his laboratory, supplies, and spectrophotometer, and to C. Guglielmo and T. Williams for providing protocols and technical assistance with metabolite assays. We thank the Colusa Grain Elevator Corporation, Illinois Department of Natural Resources, Iowa Department of Natural Resources, Kibbe Field Station, Missouri Department of Conservation, Minnesota Department of Natural Resources, RustOleum Corporation, Tri-Oak Foods, U.S. Fish and Wildlife Service Regions 3 and 6 Habitat and Population Evaluation Team (HAPET) offices, U.S. Geological Survey (USGS) National Wetland Research Center, USGS Northern Prairie Wildlife Research Center, Western Illinois University, and Federal and Winchester Cartridge companies for in-kind support. We acknowledge M. Anderson, A. Anteau, J. Fernandez, R. Hier, M. Johnson, J. Lawrence, M. Mitchell, E. Moser, J. Nyman, B. Pardo, D. Rave, J. Ringelman, S. Stephens, and G. Zenner for their help or support of the project. We thank the following organizations for financial support: Ducks Unlimited USA, Institute for Wetland and Waterfowl Research (IWWR) of Ducks Unlimited Canada, IWWR of Ducks Unlimited Canada (through the Bonnycastle Fellowship), Louisiana Department of Wildlife and Fisheries, Louisiana State University (through the Bosch Fellowship), Minnesota Department of Natural Resources, Minnesota Waterfowl Association, North Dakota Game and Fish Department, Prairie Pothole Joint Venture, Upper Mississippi River and Great Lakes Region Joint Venture, and USGS Louisiana Cooperative Fish and Wildlife Research Unit. Lastly, we thank S. McWilliams and two anonymous reviewers for helpful comments that improved this manuscript. The Louisiana State University Institutional Animal Care and Use Committee approved our experimental protocols (nos. 03-031 and 04-065).

\section{literature Cited}

Afton, A. D., ANd C. D. AnKNey. 1991. Nutrient-reserve dynamics of breeding Lesser Scaup: A test of competing hypotheses. Condor 93:89-97.

Alisauskas, R. T., And C. D. AnKney. 1992. The cost of egg laying and its relationship to nutrient reserves in waterfowl. Pages 30-61 in Ecology and Management of Breeding Waterfowl (B. D. J. Batt, A. D. Afton, M. G. Anderson, C. D. Ankney, D. H. Johnson, J. A. Kadlec, and G. L. Krapu, Eds.). University of Minnesota Press, Minneapolis.

Anteau, M. J. 2002. Nutrient reserves of Lesser Scaup during spring migration in the Mississippi Flyway: A test of the spring condition hypothesis. M.S. thesis, Louisiana State University, Baton Rouge.

Anteau, M. J. 2006. Ecology of Lesser Scaup and amphipods in the upper-Midwest: Scope and mechanisms of the spring condition hypothesis and implications for migration habitat conservation. Ph.D. dissertation, Louisiana State University, Baton Rouge.

Anteau, M. J., And A. D. Afton. 2004. Nutrient reserves of Lesser Scaup during spring migration in the Mississippi Flyway: A test of the spring condition hypothesis. Auk 121:917-929.
Anteau, M. J., And A. D. Afton. 2006. Diet shifts of Lesser Scaup are consistent with the spring condition hypothesis. Canadian Journal of Zoology 84:779-786.

Boismenu, C., G. Gauthier, and J. Larochelle. 1992. Physiology of prolonged fasting in Greater Snow Geese (Chen caerulescens atlantica). Auk 109:511-521.

Cerasale, D. J., And C. G. Guglielmo. 2006. Dietary effects on prediction of body mass changes in birds by plasma metabolites. Auk 123:836-846.

Guglielmo, C. G., D. J. Cerasale, and C. Eldermire. 2005. A field validation of plasma metabolite profiling to assess refueling performance of migratory birds. Physiological and Biochemical Zoology 78:116-125.

Guglielmo, C. G., P. D. O’Hara, and T. D. Williams. 2002. Extrinsic and intrinsic sources of variation in plasma lipid metabolites of free-living Western Sandpipers (Calidris mauri). Auk 119:437-445.

Haramis, G. M., E. L. Derleth, and D. G. McAuley. 1982. Techniques for trapping, aging, and banding wintering Canvasbacks. Journal of Field Ornithology 53:342-351.

Jenni, L., AND S. Jenni-Eiermann. 1996. Metabolic responses to diurnal feeding patterns during the postbreeding, moulting and migratory periods in passerine birds. Functional Ecology 10:73-80.

Jenni-Eiermann, S., And L. Jenni. 1994. Plasma metabolite levels predict individual body-mass changes in a small long-distance migrant, the Garden Warbler. Auk 111:888-899.

Le Maho, Y., H. Vu Van Kha, H. Koubi, G. Dewasmes, J. Girard, P. Ferre, and M. Cagnard. 1981. Body composition, energy expenditure, and plasma metabolites in long-term fasting geese. American Journal of Physiology 241:E342-E354.

Lindström, A. 2003. Fuel deposition rates in migrating birds: Causes, constraints, and consequences. Pages 307-320 in Avian Migration (P. Berthold, E. Gwinner, and E. Sonnenschein, Eds.). Springer-Verlag, New York.

PACE, R. M., III, And A. D. Afton. 1999. Direct recovery rates of Lesser Scaup banded in northwest Minnesota: Sources of heterogeneity. Journal of Wildlife Management 63:389-395.

RAMENOFSKY, M. 1990. Fat storage and fat metabolism in relation to migration. Pages 214-231 in Bird Migration: Physiology and Ecophysiology (E. Gwinner, Ed.). Springer-Verlag, New York.

Roвy, D. D. 1991. A comparison of two noninvasive techniques to measure total body lipid in live birds. Auk 108:509-518.

SAS Institute. 2002. SAS/STAT User's Guide, version 9. SAS Institute, Cary, North Carolina.

Thompson, D. 1973. Feeding ecology of diving ducks on Keokuk Pool, Mississippi River. Journal of Wildlife Management 37:367-381.

Williams, T. D., C. G. Guglielmo, O. Egeler, and C. J. MarTYNIUK. 1999. Plasma lipid metabolites provide information on mass change over several days in captive Western Sandpipers. Auk 116:994-1000.

Zajac, R. M., D. J. Cerasale, and C. G. Guglielmo. 2006. The rapid response of plasma metabolites to changes in feeding rate in a small passerine Wilsonia pusilla. Journal of Avian Biology 37:405-408.

Zar, J. H. 1996. Biostatisical Analysis, 3rd ed. Prentice Hall, Upper Saddle River, New Jersey.

Associate Editor: S. R. McWilliams 